\title{
ANALISIS FRASA ENDOSENTRIK PADA OPINI "STOP MELODRAMA" SURAT KABAR MEDIA INDONESIA EDISI 21 SEPTEMBER 2020
}

\section{ANALYSIS OF ENDOCENTRIC PHRASES IN OPINION "STOP MELODRAMA" OF MEDIA INDONESIA NEWSPAPER EDITION 21 SEPTEMBER 2020}

\author{
Nadia Indah Ratnafuri, Asep Purwo Yudi Utomo \\ Prodi Sastra Indonesia, Fakultas Bahasa dan Seni, Universitas Negeri Semarang \\ Pos-el: nadiaindah2708@gmail.com, aseppyu@mail.unnes.ac.id
}

*)Naskah diterima: 4 Januari 2021; direvisi: 7 September 2021; disetujui: 22 Oktober 2021

\begin{abstract}
Abstrak
Penelitianini bertujuanuntukmendeskripsikan penggunaan frasa endosentrik padaopini “Stop Melodrama" Surat Kabar Elektronik Media Indonesia Edisi 21 September 2020. Pendeskripsian tersebut meliputi, pola dan bentuk frasa endosentrik. Penelitian ini merupakan deskriptif kualitatif. Data pada penelitian ini bersumber pada opini "Stop Melodrama" Surat Kabar Elektronik Media Indonesia Edisi 21 September 2020. Seluruh frasa endosentrik yang terdapat dalam opini "Stop Melodrama" Surat Kabar Elektronik Media Indonesia Edisi 21 September 2020 merupakan objek penelitian dalam penelitian ini. Teknik pengumpulan data dengan metode pustaka, membaca, dan mencatat. Adapun teknik analisis data dengan teknik analisis deskriptif. Hasil penelitian ini adalah frasa memiliki jenis yang beragam didalamnya.

Penelitian ini menganalisis jenis frasa endosentrik. Ditemukan frasa endosentrik di dalamnya yaitu frasa endosentrik atributif dan farsa endosentrik apositif. Penelitian ini bermanfaat dalam pengembangan teori sintaksis tentang frasa, khususnya frasa endosentrik, dan dapat menambah pengetahuan tentang frasa endosentrik.
\end{abstract}

Kata kunci : frasa endosentrik, bentuk, pola

\begin{abstract}
This study aims to describe the use of endocentric phrases in the Opinion "Stop Melodrama" Of Electronic Newspaper Media Indonesia Edition 21 September 2020. The decryption includes, the form of endocentric phrases, the pattern of endocentric phrases. This research is descriptive qualitative. The data in this study was sourced from the Opinion "Stop Melodrama" Of Electronic Newspaper Media Indonesia Edition 21 September 2020. All endocentric phrases contained in the Opinion "Stop Melodrama" Of Electronic Newspaper Media Indonesia Edition 21 September 2020 are the object of research in this research. Library, reading, and note-taking techniques analyzed with descriptive analysis techniques. The result of this study is that the phrase has a variety of types in it. In this study analyzed types of endocentric phrases. And found endocentric phrases in it are attributeive endocentric phrases, and apositive endocentric farsa. This research is useful in the development of syntactic theory about phrases, especially endocentric phrases, and this research makes students or ordinary people can increase knowledge about endocentric phrases.
\end{abstract}

Keywords:endocentric phrases, shapes, patterns. 


\section{PENDAHULUAN}

Dalam dunia bahasa, khususnya bahasa Indonesia kita mempelajari berbagai macam cabang ilmu, salah satunya linguistik. Menurut Wiratno (2014:1), bahasa adalah alat komunikasi yang diungkapkan baik secara lisan maupun tulis. Chaer (2014:206) menyebutkan bahwa di dalam tataran linguistik atau tata bahasa juga terdapat tataran salah satunya sintaksis. Menurut Stryker dan Tarigan dalam Supriyadi (2014:1), sintaksis merupakan telaah mengenai polapola yang diperlukan sebagai sarana untuk menghubungkan kata menjadi kalimat. Sementara itu menurut Verhaar dalam Ulfa (2019:2) menyatakan cabang dalam lingusitik yang menyangkut susunan kata-kata di dalam kalimat disebut sintaksis. Parker dan Riley dalam Hasanudin (2018:20) mengatakan bahwa kalimat, klausa, dan frasa merupakan kajian-kajian yang ada di dalam sintaksis. Hal ini disebutkan dalam pendapat salah satu ahli bahasa, yaitu Ramlan dalam Najihah (2015:1), yang mengatakan bahwa bidang sintaksis dalam tataran wacana meliputi frasa, klausa, kalimat, serta hubungan antara kalimat yang satu dan kalimat yang lainnya baik sebelum maupun sesudahnya. Ilmu bahasa yang berusaha menjelaskan hubungan fungsional maupun hubungan maknawi yang berupa unsur satuan maupun hubungan antaraunsur itu dalam satuan disebut dengan sintaksis.

\section{LANDASAN TEORI}

Chaer dalam Wahidah (2019:178) menjelaskan di dalam kalimat yang mengisi salah satu fungsi sintaksis berupa gabungan kata adalah pengertian dari frasa. Parera dalam Tarmini (2019:22) menyatakan bahwa suatu konstruksi yang dapat dibentuk oleh dua kata atau tidak disebut frasa. Kana (2017:88) menjelaskan konstruksi frasa eksosentrik dan konstrusi frasa endosentrik merupakan konstruksi frasa Ahli bahasa,
Ramlan dalam Novianingsih (2012:6) mengatakan bahwa frasa endosentrik dan frasa eksosentrik merupakan dua jenis frasa yang dibagi berdasarkan kesetaraan distribusi unsur-nsurnya. Menurut Emzir (2012:101), frasa yang memiliki distribusi unsur yang sama baik semuanya atau salah satunya disebut dengan frasa endosentrik. Sementara itu menurut Surastina (2012:13), frasa yang keseluruhannya mempunyai perilaku sintaktis yang sama dengan salah satu bagiannya disebut dengan frasa endosentris. Frasa endosentrik koordinatif, frasa endosentrik atributif, dan frasa endosentrik apositif merupakan tiga jenis frasa yang terdapat dalam frasa endosentrik. Finoza dalam Rati (2018:3) mengatakan bahwa rasa yang semua unsurnya tidak memiliki distribusi yang sama disebut dengan frasa eksosentris. Kridalaksana dalam Mesyi (2020:1) menjelaskan frasa eksosentris yang direktif dan frasa eksosentris yang nondirektif merupakan jenis dari frasa eksosentris.

Dalam frasa juga dapat ditemukan diberbagai jenis teks dan media salah satunya pada surat kabar di dalam teks opini. Frasa dalam surat kabar menggunakan bahasa tulis, yang merupakan salah satu bahasa yang sangat memperhatikan kelengkapan struktur bahasa. Frasa juga memperhatikan kaidah bahasa Indonesia yang meliputi penggunaan kata, frasa, klausa, kalimat, dan wacana. Hal tersebut disebutkan dalam Rahayu (2019:182) yang menyatakan bahwa frasa endosentrik sering dijumpai pada tulisan berita berupa frasa endosentrik koordinatif, frasa endosentrik atributif, dan juga frasa endosentrik apositif. Oleh karena itu, sering ditemukan frasa di dalam surat kabar. Salah satunya di dalam surat kabar yang berupa opini.

Penelitian tentang frasa merupakan penelitan yang masih sering dilakukan oleh para ahli bahasa. Penelitian tentang frasa 
endosentrik ini sebelumnya pernah dilakukan oleh beberapa orang diantaranya Retnawati (2014), Dwaiskurny (2017), Kelen (2017). Pertama, penelitian oleh Retnawati (2014) yang berjudul Frase Endosentrik Bahasa Jawa dalam Novel Duraka Karya Any Asmara. Penelitian ini meneliti frasa dalam novel Duraka karya Any Asmara, yang menggunakan bahasa Jawa dan ditemukan makna, unsur, tipe konstruksi, dan kategori dalam frasa endosentrik. Kedua, penelitian oleh Dwaiskurny (2017) yang mengangkat judul "Analisis Frasa Endosentris dan Frasa Eksosentris dalam Kumpulan Puisi Malu Aku Jadi Orang Indonesia Karya Taufiq Ismail. Penelitian ini berisi tentang pengertian, dan jenis frasa endosentris dan frasa eksosentris serta perluasan aposisi. Ketiga, penelitian oleh Kelen (2017) yang berjudul "Struktur dan Kategori Frasa Endosentris Atributif dalam Artikel Opini Surat Kabar Kompas Edisi 1 Maret 2017". Penelitian ini meneliti opini surat kabar kompas edisi 1 Maret 2017 dan mendeskripsikan struktur, dan kategori frasa endosentris.

Dari data penelitian yang dilakukan sebelumnya, penelitian ini akan membahas tentang frasa endosentrik, bentuk frasa endosentrik, dan pola frasa endosentrik yang terdapat dalam opini 'Stop Melodrama' Surat Kabar Elektronik Media Indonesia Edisi 21 September 2020. Penelitian ini penting dilakukan karena frasa endosentrik merupakan salah satu unsur bahasa yang penting. Penggunaan frasa endosentrik, pola frasa endosentrik, dan bentuk frasa endosentrik di dalam opini "Stop Melodrama" Surat Kabar Elektronik Media Indonesia Edisi 21 September 2020 merupakan hal yang akan dideskripsikan dalam penelitian ini. Dengan diadakannya penelitian ini, diharapkan dapat bermanfaat, baik secara praktis maupun secara teoritis. Menambah pengetahuan dan wawasan mengenai bentuk frasa endosentrik, frasa endosentrik, dan pola frasa endosentrik merupakan manfaat teoritis dari penelitian ini. Penelitian ini memberikan penjelasan mengenai pola frasa endosentrik frasa endosentrik, bentuk frasa endosentrik, yang dapat meningkatkan pemahaman mengenai frasa endosentrik pada mahasiswa dan masyarakat merupakan manfaat praktis.

\section{METODE PENELITIAN}

Penelitian kualitatif merupakan jenis penelitian yang digunakan dalam penelitian ini karena subjek penelitian ini berupa kata dan bahasa yang berusaha untuk memahami kenyataan di dalamnya. Hal ini juga dijelaskan dalam Wikipedia (2020) bahwa penelitian kualitatif cenderung menggunakan analisis dan bersifat deskriptif. Penelitian ini menggunakan metode pustaka dan teknik baca dan catat dalam pengumpulan datanya. Bahasa dalam artikel ini ditulis menggunakan metode informal. Sudaryanto dalam Utomo, A. P. Y, (2019:236) menyatakan bahwa sebuah penyajian dari hasil analisis yang menggunakan kata-kata biasa disebut dengan metode informal. Teknik pustaka berupa subjek dan objek penelitian. Opini "Stop Melodrama" Surat Kabar Elektronik Media Indonesia Edisi 21 September 2020 merupakan subjek dalam penelitian ini. Objek penelitian ini berupa frasa endosentrik yang terdapat pada opini "Stop Melodrama" Surat Kabar Elektronik Media Indonesia Edisi 21 September 2020. Dalam penelitian ini seluruh data frasa endosentrik pada opini "Stop Melodrama" Surat Kabar Elektronik Media Indonesia Edisi 21 September 2020 dikaji atau dibahas.

Menurut Sudaryanto dalam Najihah (2015:6), fenomena lingual khusus yang mengandung dan berkaitan langsung dengan masalah yang dimaksud disebut dengan data. Menurut Mills dalam Putra (2020), fakta mentah observasi atau kejadian berupa angka atau simbol khusus disebut data. Ka- 
limat-kalimat dalam Opini "Stop Melodrama" Surat Kabar Elektronik Media Indonesia Edisi 21 September 2020 yang mengandung frasa endosentrik merupakan data dalam penelitian ini. Opini "Stop Melodrama" Surat Kabar Elektronik Media Indonesia Edisi 21 September 2020 merupakan sumber data penelitian ini. Data-data yang diperoleh dan dipergunakan dalam penelitian ini merupakan data dari sumber korpus, yaitu opini dalam surat kabar ini.

Teknik baca dan teknik catat merupakan teknik yang digunakan dalam penelitian ini. Data diperoleh dengan membaca opini "Stop Melodrama" Surat Kabar Elektronik Media Indonesia Edisi 21 September 2020 secara cermat, teliti, dan berulang-ulang. Membaca opini "Stop Melodrama" Surat Kabar Elektronik Media Indonesia Edisi 21 September 2020 dilakukan dengan tujuan untuk menemukan frasa endosentrik yang merupakan data dalam penelitian ini dengan melakukan beberapa langkah. Pertama, membedah klausa maupun kalimat berdasarkan unsur langsung kemudian menginterpretasinya jika data tersebut termasuk frase endosentrik. Langkah kedua, mendeskripsikan frasa yang termasuk dalam tipe konstruksi frasa endosentrik apositif, koordinatif, dan atributif berdasarkan tipe konstruksi frasa endosentrik. Langkah ketiga, mencari dan menganalisis kategori frasa endosentrik beserta deskripsinya. Langkah keempat, mencari dan menganalisis unsur-unsur pembentuk frase endosentrik. Selanjutnya, melakukan tahap pencatatan pada kertas atau buku catatan. Setelah semua data yang telah terkumpul dengan menggunakan teknik membaca dan mencatat, datadata tersebut kemudian dijadikan satu dan dilakukan analisis data yang sesuai dengan penelitian.

\section{HASIL DAN PEMBAHASAN}

Ditemukan beberapa data yang diperoleh dari hasil pengamatan berdasarkan teknik membaca dan teknik mencatat. Peneliti menemukan data analisis berupa frasa endosentrik dalam opini "Stop Melodrama" Surat Kabar Elektronik Media Indonesia Edisi 21 September 2020 yang ditulis oleh Hutabarat. Frasa endosentrik merupakan cakupan frasa yang diteliti di dalam penelitian ini. Ramlan dalam Kelen (2017:2) mengatakan bahwa frasa memiliki dua sifat, yaitu satuan gramatik yang terdiri dari dua kata atau lebih yang disebut frasa, dan satuan gramatik yang tidak melebihi batas fungsi unsur klausa, yaitu subjek, predikat, objek, pelengkap, dan keterangan yang disebut frasa. Berdasarkan hal tersebut, tipe konstruksi frasa endosentrik dalam opini "Stop Melodrama" Surat Kabar Elektronik Media Indonesia Edisi 21 September 2020 dapat dikelompokkan dalam dua tipe, yaitu frasa endosentrik apositif dan frasa endosentrik atributif.

Dijelaskan dalam Ramadhani (2018:26), frasa yang distribusi unsur-unsurnya setara dalam kalimat disebut dengan frasa endosentris. Kedudukan frasa dalam fungsi tertentu pada frasa endosentris dapat digantikan oleh unsurnya. Unsur pusat (UP) merupakan unsur dalam frasa yang dapat menggantikan frasa itu dalam fungsi tertentu. Oleh karena itu, frasa endosentris memiliki unsur pusat (UP). Parera dalam Astighfarani (2020:197) menjelaskan bahwa frasa endosentrik atributif, frasa endosentrik koordinatif, dan farsa endosentrik apositif merupakan jenis dari frasa endosentris. Jenis-jenis frasa endosentrik yang terdapat dalam opini "Stop Melodrama" Surat Kabar Elektronik Media Indonesia Edisi 21 September 2020 adalah sebagai berikut.

\section{Frasa endosentrik atributif}

Chaer dalam Melani (2019:213) menjelaskan bahwa frasa yang dapat didahului atau diikuti oleh modifikator dan memiliki satu inti disebut frasa endosentrik atributif. Penelitian fra- 
sa endosentrik atributif dalam opini "Stop Melodrama" Surat Kabar Elektronik Media Indonesia Edisi 21 September 2020 merupakan penelitian frasa yang salah satu unsurnya merupakan unsur inti atau unsur pusat dan atribut karena unsur-unsur langsung atau intinya tidak setara. Pokok yang dijelaskan disebut dengan unsur inti, sedangkan yang menjelaskan inti disebut dengan atribut.

DATA 1: Dihukum di ruang publik

\begin{tabular}{|l|l|}
\hline KATEGORI & ANALISIS \\
\hline & $\begin{array}{l}\text { Dihukum di ruang } \\
\text { publik }\end{array}$ \\
\hline Frasa endosentrik & Ruang publik \\
\hline Kata benda (UP) & Ruang \\
\hline Kata sifat (Atr) & Publik \\
\hline Jenis frasa endosentrik & $\begin{array}{l}\text { Frasa endosentrik } \\
\text { atributif }\end{array}$ \\
\hline
\end{tabular}

\section{Analisis:}

- dihukum di ruang publik

(Opini "Stop Melodrama" Surat Kabar Elektronik Media Indonesia Edisi 21 September 2020 oleh Hutabarat)

Dari data tersebut kemudian dilakukan analisis lebih lanjut. Analisis lebih lanjut ini dilakukan untuk memerinci penjelasan berdasarkan unsur pembentuk serta pola dari frasa di atas. Dari data di atas ditemukan frasa ruang publik. Dengan unsur pembentuk atau pola kontruksi frasa ruang publik yang berupa kata benda 'ruang' kemudian diikuti dengan kata sifat 'publik' merupakan frasa endosentrik atributif. Unsur inti yang ditemukan adalah kata 'ruang'. Sementara itu, atribut yang ditemukan adalah kata 'publik' yang bertujuan untuk menjelaskan kata intinya.

DATA 2: Mengenakan rompi oranye

\begin{tabular}{|l|l|}
\hline KATEGORI & ANALISIS \\
\hline & $\begin{array}{l}\text { Mengenakan rompi } \\
\text { oranye }\end{array}$ \\
\hline
\end{tabular}

\begin{tabular}{|l|l|}
\hline Frasa endosentrik & Rompi oranye \\
\hline Kata benda (UP) & Rompi \\
\hline Kata sifat (Atr) & Oranye \\
\hline Jenis frasa endosentrik & $\begin{array}{l}\text { Frasa endosentrik } \\
\text { atributif }\end{array}$ \\
\hline
\end{tabular}

\section{Analisis:}

- mengenakan rompi oranye

(Opini “Stop Melodrama” Surat Kabar Elektronik Media Indonesia Edisi 21 September 2020 oleh Hutabarat)

Dari data tersebut kemudian dilakukan analisis lebih lanjut. Analisis lebih lanjut ini dilakukan untuk memerinci penjelasan berdasarkan unsur pembentuk serta pola dari frasa di atas. Dari data di atas dapat ditemukan frasa rompi oranye. Dengan unsur pembentuk atau pola kontruksi frasa rompi oranye yang berupa kata benda 'rom$p i$ ' kemudian diikuti dengan kata sifat 'ora$n y e^{\prime}$ merupakan frasa endosentrik atributif. Unsur inti yang ditemukan adalah kata 'rompi', sedangkan atribut yang ditemukan adalah kata 'oranye' yang bertujuan untuk menjelaskan kata intinya.

DATA 3: .... dihukum masuk ke peti mati, untuk merenung selama 1-3 menit.

\begin{tabular}{|l|l|}
\hline KATEGORI & ANALISIS \\
\hline & $\begin{array}{l}\text {... dihukum masuk } \\
\text { ke peti mati, untuk } \\
\text { merenung selama 1-3 } \\
\text { menit. }\end{array}$ \\
\hline Frasa endosentrik & Peti mati \\
\hline Kata benda (UP) & Peti \\
\hline Kata sifat (Atr) & Mati \\
\hline Jenis frasa endosentrik & $\begin{array}{l}\text { Frasa endosentrik } \\
\text { atributif }\end{array}$ \\
\hline
\end{tabular}

\section{Analisis:}

- .... dihukum masuk ke peti mati, untuk merenung selama 1-3 menit. (Opini “Stop Melodrama” Surat Kabar Elektronik Media Indonesia Edisi 21 September 2020 oleh Hutabarat) 
Dari data tersebut kemudian dilakukan analisis lebih lanjut. Analisis lebih lanjut ini dilakukan untuk memerinci penjelasan berdasarkan unsur pembentuk serta pola dari frasa dipisah. Dari data di atas dapat ditemukan frasa peti mati. Dengan unsur pembentuk atau pola kontruksi frasa peti mati yang berupa kata benda 'peti' kemudian diikuti dengan kata sifat 'mati' merupakan frasa endosentrik atributif. Unsur inti yang ditemukan adalah kata 'peti' dan atribut yang ditemukan adalah kata 'mati' yang bertujuan untuk menjelaskan kata intinya.

DATA 4: Obat mujarab yang berkemampuan mengubah ...

\begin{tabular}{|l|l|}
\hline KATEGORI & ANALISIS \\
\hline & $\begin{array}{l}\text { Obat mujarab yang } \\
\text { berkemampuan } \\
\text { mengubah ... }\end{array}$ \\
\hline Frasa endosentrik & Obat mujarab \\
\hline Kata benda (UP) & Obat \\
\hline Kata sifat (Atr) & Mujarab \\
\hline Jenis frasa endosentrik & $\begin{array}{l}\text { Frasa endosentrik } \\
\text { atributif }\end{array}$ \\
\hline
\end{tabular}

- Analisis:

obat mujarab yang berkemampuan mengubah ...

(Opini "Stop Melodrama” Surat Kabar Elektronik Media Indonesia Edisi 21 September 2020 oleh Hutabarat)

Dari data tersebut kemudian dilakukan analisis lebih lanjut. Analisis lebih lanjut ini dilakukan untuk memerinci penjelasan berdasarkan unsur pembentuk serta pola dari frasa di atas. Dari data di atas ditemukan frasa obat mujarab. Dengan unsur pembentuk atau pola kontruksi frasa obat mujarab yang berupa kata benda 'obat' kemudian diikuti dengan kata sifat 'mujarab' merupakan frasa endosentrik atributif. Unsur inti yang ditemukan adalah kata 'obat' dan atribut yang ditemukan adalah kata 'mujarab' yang bertujuan untuk menjelaskan kata intinya.
DATA 5: .... meninggal langsung dibawa dari rumah sakit ke permakaman.

\begin{tabular}{|l|l|}
\hline KATEGORI & ANALISIS \\
\hline & $\begin{array}{l}\text {...meninggal langsung } \\
\text { dibawa dari rumah } \\
\text { sakit ke permakaman. }\end{array}$ \\
\hline Frasa endosentrik & Rumah sakit \\
\hline Kata benda (UP) & Rumah \\
\hline Kata sifat (Atr) & Sakit \\
\hline Jenis frasa endosentrik & $\begin{array}{l}\text { Frasa endosentrik } \\
\text { atributif }\end{array}$ \\
\hline
\end{tabular}

\section{Analisis:}

- ... meninggal langsung dibawa dari rumah sakit ke permakaman. (Opini “Stop Melodrama” Surat Kabar Elektronik Media Indonesia Edisi 21 September 2020 oleh Hutabarat)

Dari data tersebut kemudian dilakukan analisis lebih lanjut. Analisis lebih lanjut ini dilakukan untuk memerinci penjelasan berdasarkan unsur pembentuk serta pola dari frasa di atas. Dari data di atas ditemukan frasa rumah sakit. Dengan unsur pembentuk atau pola kontruksi frasa rumah sakit yang berupa kata benda 'rumah' kemudian diikuti dengan kata sifat 'sakit' merupakan frasa endosentrik atributif. Unsur inti yang ditemukan adalah kata 'rumah'. Sementara itu, atribut yang ditemukan adalah kata 'sakit' yang bertujuan untuk menjelaskan kata intinya. 
DATA 6: Sekalipun jenazah tetap berada di mobil jenazah

\begin{tabular}{|l|l|}
\hline KATEGORI & ANALISIS \\
\hline Frasa endosentrik & $\begin{array}{l}\text { Sekalipun jenazah tetap } \\
\text { berada di mobil jenazah }\end{array}$ \\
\hline Kata benda (UP) & Mobil jenazah \\
\hline Kata benda (Atr) & Jenazah \\
\hline Jenis frasa endosentrik & $\begin{array}{l}\text { Frasa endosentrik } \\
\text { atributif }\end{array}$ \\
\hline
\end{tabular}

\section{Analisis:}

- Sekalipun jenazah tetap berada di mobil jenazah

(Opini “Stop Melodrama” Surat Kabar Elektronik Media Indonesia Edisi 21 September 2020 oleh Hutabarat)

Dari data tersebut kemudian dilakukan analisis lebih lanjut. Analisis lebih lanjut ini dilakukan untuk memerinci penjelasan berdasarkan unsur pembentuk serta pola dari frasa di atas. Hasil di atas ditemukan frasa mobil jenazah. Dengan unsur pembentuk atau pola kontruksi frasa mobil jenazah yang berupa kata benda 'mobil' kemudian diikuti dengan kata benda 'jenazah' merupakan frasa endosentrik atributif. Unsur inti yang ditemukan adalah kata 'mobil'. Sementara itu, atribut yang ditemukan adalah kata 'jenazah' yang bertujuan untuk menjelaskan kata intinya.

\section{DATA 7: Orang malah riang gembira} menjepretnya dengan kamera HP

\begin{tabular}{|l|l|}
\hline KATEGORI & ANALISIS \\
\hline & $\begin{array}{l}\ldots . . \quad \text { riang gembira } \\
\text { menjepretnya dengan } \\
\text { kamera HP }\end{array}$ \\
\hline Frasa endosentrik & Kamera HP \\
\hline Kata benda (UP) & Kamera \\
\hline Kata benda (Atr) & HP \\
\hline Jenis frasa endosentrik & $\begin{array}{l}\text { Frasa endosentrik } \\
\text { atributif }\end{array}$ \\
\hline
\end{tabular}

\section{Analisis:}

- $\quad$.... riang gembira menjepretnya dengan kamera HP

(Opini “Stop Melodrama” Surat Kabar Elektronik Media Indonesia Edisi 21 September 2020 oleh Hutabarat)

Dari data tersebut kemudian dilakukan analisis lebih lanjut. Analisis lebih lanjut ini dilakukan untuk memerinci penjelasan berdasarkan unsur pembentuk serta pola dari frasa di atas. Dari data di atas ditemukan frasa kamera HP. Dengan unsur pembentuk atau pola kontruksi frasa kamera HP yang berupa kata benda 'kamera' kemudian diikuti dengan kata sifat ' $H P^{\prime}$ merupakan frasa endosentrik atributif. Unsur inti yang ditemukan adalah kata 'kamera'. Sementara itu, atribut yang ditemukan adalah kata ' $H P^{\prime}$ yang bertujuan untuk menjelaskan kata intinya.

DATA 8: Diberitakan bahkan di halaman
depan
\begin{tabular}{|l|l|}
\hline KATEGORI & ANALISIS \\
\hline & $\begin{array}{l}\text { Diberitakan bahkan di } \\
\text { halaman depan }\end{array}$ \\
\hline Frasa endosentrik & Halaman depan \\
\hline Kata benda (UP) & Halaman \\
\hline Kata benda (Atr) & Depan \\
\hline Jenis frasa endosentrik & $\begin{array}{l}\text { Frasa endosentrik } \\
\text { atributif }\end{array}$ \\
\hline
\end{tabular}

\section{Analisis :}

- diberitakan bahkan di halaman depan (Opini “Stop Melodrama” Surat Kabar Elektronik Media Indonesia Edisi 21 September 2020 oleh Hutabarat)

Dari data tersebut kemudian dilakukan analisis lebih lanjut. Analisis lebih lanjut ini dilakukan untuk memerinci penjelasan berdasarkan unsur pembentuk serta pola dari frasa diatas. Dari data di atas ditemukan frasa halaman depan. Dengan unsur pem- 
bentuk atau pola kontruksi frasa halaman depan yang berupa kata benda 'halaman' kemudian diikuti dengan kata benda 'depan' merupakan frasa endosentrik atributif. Unsur inti yang ditemukan adalah kata 'halaman'. Sementara itu, atribut yang ditemukan adalah kata 'depan' yang bertujuan untuk menjelaskan kata intinya.

DATA 9: Banyak anak manusia di sebuah Negara

\begin{tabular}{|l|l|}
\hline KATEGORI & ANALISIS \\
\hline Frasa endosentrik & $\begin{array}{l}\text { Banyak anak manusia } \\
\text { di sebuah Negara }\end{array}$ \\
\hline Kata benda (UP) & Anak manusia \\
\hline Kata benda (Atr) & Manusia \\
\hline Jenis frasa endosentrik & $\begin{array}{l}\text { Frasa endosentrik } \\
\text { atributif }\end{array}$ \\
\hline
\end{tabular}

\section{Analisis :}

- banyak anak manusia di sebuah Negara.

(Opini "Stop Melodrama” Surat Kabar Elektronik Media Indonesia Edisi 21 September 2020 oleh Hutabarat)

Dari data tersebut kemudian dilakukan analisis lebih lanjut. Analisis lebih lanjut ini dilakukan untuk Memerinci penjelasan berdasarkan unsur pembentuk serta pola dari frasa di atas. Dari data di atas ditemukan frasa anak manusia. Dengan unsur pembentuk atau pola kontruksi frasa anak manusia yang berupa kata benda 'anak' kemudian diikuti dengan kata benda 'manusia' merupakan frasa endosentrik atributif. Unsur inti yang ditemukan adalah kata 'anak'. Sementara itu, atribut yang ditemukan adalah kata 'manusia' yang bertujuan untuk menjelaskan kata intinya.
DATA 10: Hukuman sosial itu berbasiskan rasa malu

\begin{tabular}{|l|l|}
\hline KATEGORI & ANALISIS \\
\hline Frasa endosentrik & $\begin{array}{l}\text { Hukuman sosial itu } \\
\text { berbasiskan rasa malu }\end{array}$ \\
\hline Kata kerja (UP) & Hukuman sosial \\
\hline Kata sifat (Atr) & Hukuman \\
\hline Jenis frasa endosentrik & $\begin{array}{l}\text { Frasa endosentrik } \\
\text { atributif }\end{array}$ \\
\hline
\end{tabular}

\section{Analisis:}

- Hukuman sosial itu berbasiskan rasa malu

(Opini “Stop Melodrama” Surat Kabar Elektronik Media Indonesia Edisi 21

September 2020 oleh Hutabarat)

Dari data tersebut kemudian dilakukan analisis lebih lanjut. Analisis lebih lanjut ini dilakukan untuk Memerinci penjelasan berdasarkan unsur pembentuk serta pola dari frasa. Dari data di atas ditemukan frasa hukuman sosial. Dengan unsur pembentuk atau pola kontruksi frasa hukuman sosial yang berupa kata kerja 'hukuman' kemudian diikuti dengan kata sifat 'sosial' merupakan frasa endosentrik atributif. Unsur inti yang ditemukan adalah kata 'hukuman'. Sementara itu, atribut yang ditemukan adalah kata 'sosial' yang bertujuan untuk menjelaskan kata intinya.

Menurut Kushartanti dalam Dwaiskurny (2017:6), frasa yang dapat didahului atau diikuti oleh modifikator dan mengandung satu inti disebut dengan frasa endosentris atributif, yang terdiri atas salah satu kelas kata, seperti nomina, verba, numeralia, ajektiva, atau adverbia dalam inti maupun modifikatornya. Oleh karena itu, frasa ruang publik, frasa rompi oranye, frasa peti mati, frasa obat mujarab, frasa rumah sakit, frasa mobil jenazah merupakan frasa endosentrik atributif. 


\section{Frasa endosentrik apositif}

Tarigan (2009:105) menjelaskan bahwa frasa yang kedua intinya tidak dapat dihubungkan oleh konektor karena frasa berinti dua dan kedua inti itu tidak mempunyai referen yang sama disebut dengan frasa endosentris apositif.

DATA 1: .... muncul kritik ketika jenazah Saefullah, Sekda Pemprov Jakarta...

\begin{tabular}{|l|l|}
\hline KATEGORI & ANALISIS \\
\hline & $\begin{array}{l}\text {...muncul kritik ketika } \\
\text { jenazah Saefullah, } \\
\text { Sekda Pemprov Jakarta } \\
\ldots\end{array}$ \\
\hline Frasa endosentrik & $\begin{array}{l}\text { Saefullah, Sekda } \\
\text { Pemprov Jakarta }\end{array}$ \\
\hline Kata benda (UP) & Saefullah \\
\hline & Sekda Pemprov Jakarta \\
\hline Jenis frasa endosentrik & $\begin{array}{l}\text { Frasa endosentrik } \\
\text { apositif }\end{array}$ \\
\hline
\end{tabular}

\section{Analisis:}

- ... muncul kritik ketika jenazah Saefullah, Sekda Pemprov Jakarta ... (Opini "Stop Melodrama” Surat Kabar Elektronik Media Indonesia Edisi 21 September 2020 oleh Hutabarat)

Frasa Saefullah, Sekda Pemprov Jakarta merupakan frasa bertipe endosentris apositif. Frasa Saefullah, Sekda Pemprov Jakarta merupakan kata benda sehingga, tipe kontruksi frasa endosentris apositif berupa kategori kata benda. Unsur inti berupa frasa Saefullah, Sekda Pemprov Jakarta. Unsur yang pertama atau kedua saling menjelaskan. Kata 'Saefullah' dengan frasa'Sekda Pemprov Jakarta' memiliki makna yang sama. Finoza dalam Rati (2018:9) menyatakan bahwa hubungan yang menjelaskan sekaligus dapat berperan sebagai pengganti bagian yang dijelaskan disebut dengan hubungan apositif.

Penelitian frasa endosentrik ini merupakan pendeskripsian dari permasalahan pada rumusan masalah, yaitu pembahasan me- ngenai frasa endosentrik dalam opini "Stop Melodrama" Surat Kabar Elektronik Media Indonesia Edisi 21 September 2020 yang menemukan tipe frasa endosentrik, bentuk frasa endosentrik, dan pola frasa endosentrik. Hal tersebut juga ditemukan pada penelitian sebelumnya. Ditemukan dua tipe frasa endosentrik dalam Opini "Stop Melodrama" Surat Kabar Elektronik Media Indonesia Edisi 21 September 2020 berdasarkan sifat frasa, yaitu tipe konstruksi frasa endosentrik atributif dan tipe konstruksi frasa endosentrik apositif. Hal ini juga ditemukan pada penelitian sebelumnya. Namun, dalam penelitian ini juga terdapat perbedaan dengan penelitian sebelumnya, yaitu tidak ditemukannya kontruksi frasa endosentrik koordinatif seperti pada penelitian sebelumnya. Hal baru yang didapatkan dari penelitian yang berjudul Analisis Penggunaan Frasa Endosentrik pada Opini "Stop Melodrama" Surat Kabar Elektronik Media Indonesia Edisi 21 September 2020 ini adalah frasa endosentrik yang terdapat di dalam opini "Stop Melodrama" Surat Kabar Elektronik Media Indonesia Edisi 21 September 2020. Manfaat dan kontribusi penelitian Penggunaan Frasa Endosentrik pada Opini "Stop Melodrama" Surat Kabar Elektronik Media Indonesia Edisi 21 September 2020 dalam bidang keilmuan adalah pengembangan teori sintaksis tentang frasa, khususnya frasa endosentrik. Bagi mahasiswa dan masyarakat, penelitian tentang Penggunaan Frasa Endosentrik pada Opini "Stop Melodrama" Surat Kabar Elektronik Media Indonesia Edisi 21 September 2020 ini dapat menambah wawasan dan pengetahuan tentang sintaksis, khusunya pada frasa endosentrik.

\section{PENUTUP}

Pembahasan frasa endosentrik dalam penelitian Analisis Penggunaan Frasa Endosentrik pada Opini "Stop Melodrama" Surat Kabar Elektronik Media Indonesia Edisi 21 September 2020 menemukan sebuah opini de- 
ngan tiga tipe kontruksi frasa endosentrik. Data dalam penelitian ini dijelaskan dengan bentuk tabel dan tulisan. Dapat disimpulkan bahwa pada opini "Stop Melodrama" Surat Kabar Elektronik Media Indonesia Edisi 21 September 2020 ditemukan tipe frasa endosentrik, bentuk frasa endosentrik, dan pola frasa endosentrik. Berdasarkan konstruksinya, dalam penelitian ini hanya ditemukan dua jenis frasa endosetrik, yaitu frasa endosentrik atributif dan frasa endosentrik apositif pada beberapa kalimatnya. Oleh karena itu, peneliti lain diharapkan dapat melanjutkan penelitian dengan lebih baik dan lebih terperinci dalam menganalisis frasa, seperti menganalisis frasa endosentrik yang terdapat pada objek lain yang berupa frasa endosentrik berinduk tunggal maupun frasa endosentrik berinduk jamak.

\section{DAFTAR PUSTAKA}

Astighfarani, S. A. 2020. Analisis Kesalahan Penulisan Frasa Endosentris Dan Eksosentris Pada Kolom Opini Tanjungpinang Pos Edisi April 2019. Student Online Journal (SOJ) UMRAH, 195-203.

Chaer, A. 2014. Linguistik Umum. Jakarta : Rineka Cipta.

Dwaiskurny. 2017. Analisis Frasa Endosentris Dan Frasa Eksosentri Sdalam Kumpulan Puisi “Malu Aku Jadi Orang Indonesia" Karya Taufiq Ismail. Jurnal. umrah.ac.id, 1-9.

Emzir. 2012. Metodelogi Penelitian Pendidikan Kuantitatif dan Kualitatif. Jakarta: PT Raja Grafindo Persada.

Mesyi. 2020. Frasa Eksosentris Dalam Novel Anak Rantau Karya A. Fuadi. ejurnal.bunghatta.ac.id, 1-2.

Hasanudin, C. 2018. Kajian sintaksis pada novel sang pencuri warna karya yersita. Jurnal Pendidikan Edutama, 19-30.

Hutabarat, S. M. 2020, September 21). Setop Melodrama. Retrieved from MEDIA INDONESIA: https:/ / mediaindonesia. com/read/detail/346392-setop-melodrama.

Kana, N. 2017. Struktur Frase Endosentrik Bahasa Dondo Di Desa Batuilo Kecamatan Ogodeide Kabupaten Toli-Toli. Bahasa Dan Sastra, 86-99.

Kelen, M. Y. 2017. Struktur dan Kategori Frasa Endosentris Atributif dalam Artikel Opini Surat Kabar Kompas Edisi 1-4 Maret 2017. Jurnal.usd.ac.id, 1-166.

Melani. 2019. Annalisis Frasa Pada Surat Kabr Bengkulu. Jurnal Ilmiah Korpus.

Najihah, M. 2015. Frasa Eksosentris dalam Novel Sebelas Patriot Karya Andrea Hirata . Jurnal.ums.ac.id, 1-12.

Novianingsih. 2012. Bentuk Frasa Pada Wacana Buku Teks Bahasa Indonesia Kelas XII SMA Karangan Dawud Dkk Penerbit: Erlangga 2004. Jurnal Publikasi, 1-15.

Putra. 2020, Februari 2). PENGERTIAN DATA: Fungsi, Sumber, Jenis Jenis Data dan Contohnya. Retrieved from Salamadian: https:/ / salamadian.com/pengertian-data/

Rahayu. 2019. Penggunaan Frasa Endosentrik Apositif Dalam Karangan Wacana Berita. AIJER, 181-186.

Ramadhani, C. 2018. Penggunaan Frasa Endosentrik Apositif Pada Wacana Berita Di Rubrik Go Cakrawala. Jurnal.unismuh.ac.id, 1-91.

Retnawati, V. 2014. Frase Endosentrik Bahasa Jawa Dalam Novel Duraka Karya Any Asmara. Junal.uny.ac.id, 1-214.

Ulfa, R. 2019. Frasa Endosentris Dalam Novel Jilbab Traveler Love Sparks In Korea Karya Asma Nadia. ummuhjember. ac.id, 1-14.

Rati, S. 2018. Analisis Frasa Endosentris Dan Eksosentris Pada Novel Supernova Akar Karya Dewi Lestari. Jurnal.umrah. ac.id, 1-14.

Melani, S. 2019. Analisis Frasa Pada Surat Kabar Harian Rakyat Bengkulu. Jurnal Ilmiah KORPUS, 210-220. 
Supriyadi. 2014). Sintaksis Bahasa Indonesia. Gorontalo: UNG Press.

Surastina. (2012). Frasa Dalam Bahasa Indonesia. Lentera Jurnal Ilmiah Kependidikan, 18-35.

Tarmini, W. (2019). Sintaksis Bahasa Indonesia. Jakarta: UHAMKA Press.

Utomo, A. P. Y., Haryadi, H., Fahmy, Z., \& Indramayu, A. (2019). Kesalahan Bahasa pada Manuskrip Artikel Mahasiswa di Jurnal Sastra Indonesia. Jurnal Sastra Indonesia, 8(3), 234-241.

Wahidah, B. Y. (2019). Komparasi Berbagai Definisi Mengenai Frasa dan Kata Ma- jemuk Dalam Media Sosial Google Berdasarkan Kajian Sintaksis. JUPE: Jurnal Pendidikan Mandala, 178-182.

Wikipedia. (2020, Desember 4). Penelitian kualitatif. Retrieved from Wikipedia: https://id.wikipedia.org/wiki/Penelitian_kualitatif.

Wiratno. (2014). Bahasa, Fungsi Bahasa, dan Konteks Sosial. Modul Pengantar Linguistik Umum, 1-19. 